\title{
Vegan tempeh burger: prepared with aged bean grains fermented by Rhizopus
}

\section{oligosporus inoculum}

\author{
Hambúrguer vegano de tempeh: preparado com grãos de feijão envellhecidos fermentados por \\ inóculo de Rhizopus oligosporus
}

Hamburguesa vegana tempeh: preparada con granos de frijoles añejos fermentados con inóculo de

\section{Rhizopus oligosporus}

Received: 01/30/2021 | Reviewed: 02/07/2021 | Accept: 02/10/2021 | Published: 02/20/2021

\author{
Juliana Aparecida Correia Bento \\ ORCID: https://orcid.org/0000-0001-9015-9426 \\ Federal University of Goiás, Brazil \\ E-mail: julianaap.ufg@gmail.com \\ Priscila Zaczuk Bassinello \\ ORCID: https://orcid.org/0000-0002-8545-9501 \\ EMBRAPA Rice and Beans, Brazil \\ E-mail: priscila.bassinello@embrapa.br \\ Aline Oliveira Colombo \\ ORCID: https://orcid.org/0000-0002-2198-0760 \\ Federal University of Goiás, Brazil \\ E-mail: colomboaline@yahoo.com.br \\ Rayane Jesus Vital \\ ORCID: https://orcid.org/0000-0002-5194-8905 \\ Paulista University, Brazil \\ E-mail: rayanevitalnutri@gmail.com \\ Rosângela Nunes Carvalho \\ ORCID: https://orcid.org/0000-0002-6862-8940 \\ EMBRAPA Rice and Beans, Brazil \\ E-mail: rosangela.carvalho@embrapa.br
}

\begin{abstract}
This work has the objective of producing inoculum to enable tempeh production from aged common bean, by checking fermentation development according to the soybean/common bean ratio and defining the procedure for tempeh preparing in compliance with regulation on standards for acceptable microbiological contamination. Tempehs of common bean (BT), soybean (ST) and both (SBT) were produced by two methods (traditional and modified). The viable BT was used for hamburger preparation, which was evaluated for sensory acceptance in comparison to the traditional ST. The best inoculum Rhizopus oligosporus obtained was made with a medium with rice flour and presented a cell concentration of $10^{6} \mathrm{cell} / \mathrm{s} / \mathrm{mL}$. Tempehs made in a traditional method presented a bacterium grown beyond limit allowed by regulation. Instead, the modified method can be recommended to the industries to ensure the sanitary quality of tempeh. Finally, BT hamburger had a good acceptance (58\%) regarding general appearance, but its flavor must be improved.
\end{abstract}

Keywords: Phaseolus vulgaris L; Glycine max L; Solid fermentation; Contamination; Autoclaving.

\section{Resumo}

Este trabalho tem como objetivo produzir inóculo para viabilizar a produção de tempeh a partir do feijão envelhecido, verificando o desenvolvimento da fermentação segundo a relação soja / feijão comum e definindo o procedimento de preparo do tempeh de acordo com a regulamentação dos padrões de contaminação microbiológica aceitável. Tempehs de feijão (BT), soja (ST) e ambos (SBT) foram produzidos por dois métodos (tradicional e modificado). O BT viável foi utilizado para o preparo de hambúrguer, que foi avaliado quanto à aceitação sensorial em comparação ao ST tradicional. O melhor inóculo obtido de Rhizopus oligosporus foi feito com meio de farinha de arroz e apresentou concentração celular de $10^{6}$ células/mL. Tempehs feitos em um método tradicional apresentaram contagem de bactérias além do limite permitido pela regulamentação. Logo, o método modificado pode ser recomendado às indústrias para garantir a qualidade sanitária do tempeh. Por fim, o hambúrguer BT teve uma boa aceitação (58\%) quanto ao aspecto geral, mas seu sabor deve ser aprimorado.

Palavras-chave: Phaseolus vulgaris L; Glycine max L; Fermentação sólida; Contaminação; Autoclavagem. 


\section{Resumen}

Este trabajo tiene como objetivo producir inóculo que permita la producción de tempeh a partir de frijol común envejecido, mediante el control del desarrollo de la fermentación de acuerdo con la relación soja / frijol común y definiendo el procedimiento de preparación del tempeh de acuerdo con la normativa sobre estándares de contaminación microbiológica aceptable. Los tempehs de frijol común (BT), soja (ST) y ambos (SBT) fueron producidos por dos métodos (tradicional y modificado). El BT viable se utilizó para la preparación de hamburguesas, cuya aceptación sensorial se evaluó en comparación con el ST tradicional. El mejor inóculo de Rhizopus oligosporus obtenido fue elaborado con un medio con harina de arroz y presentó una concentración celular de $10^{6}$ células $/ \mathrm{mL}$. Los tempeh elaborados con un método tradicional presentaban una bacteria que crecía más allá del límite permitido por la regulación. En cambio, el método modificado puede recomendarse a las industrias para garantizar la calidad sanitaria del tempeh. Finalmente, la hamburguesa BT tuvo una buena aceptación (58\%) en cuanto al aspecto general, pero hay que mejorar su sabor.

Palabras clave: Phaseolus vulgaris L; Glycine max L; Fermentación sólida; Contaminación; Autoclave.

\section{Introduction}

The constant evolution of food industry has been showing technological and scientific progress on development of new products. Healthy eating, convenient products and the rapid change of consumer tastes stimulate the consumption of innovative products (Yannakoulia et al., 2018). Following this trend, tempeh, a traditional Indonesian food produced by fermentation of soybean using Rhizopus fungi species (Nakajima, Nozaki, Ishihara, Ishikawa, \& Tsuji, 2005) is regarded as an interesting source of protein, vitamin B complex, such as vitamin B12, soluble dietary fiber and bioactive compounds, showing antioxidant activity, reducing antinutritional factors and increasing legume digestibility (Bento, Bassinello, Colombo, Vital, \& Carvalho, 2020).

Additionally, from soybean, tempeh can be produced from many other substrates. Although unusual, there is a growing interest in alternative tempeh from sources such as peas, barley, corn, rice, lentils and beans. The carioca group beans are the most cultivated and consumed in Brazil. However, the integument of this bean darkens very quickly during storage and the bean itself also hardens rapidly, economically depreciating the product (Bento, Lanna, et al., 2020; de Farias, Devilla, Silva, Bento, $\&$ Bassinello, 2020). Therefore, the use of these aged grains as ingredient in the development of new products is an alternative to reuse these, in addition to providing foods with high nutritional value (Bassinello, Bento, Gomes, Caliari, \& Oomah, 2020; Bento, Bassinello, et al., 2020; Krisnawati \& Adie, 2015). The growing potential of domestic and foreign markets for special types of beans attracts the interest of gourmet gastronomy (haute cuisine), the use in different culinary preparations and in food industry, aside from usual "cooked grain" form (Bassinello et al., 2020). Moreover, the bean tempeh can be used in the development of gluten-free and vegan products, as a hamburger, which in turn is one of the most prosperous markets in the field of the food industry (Bascunan, Vespa, \& Araya, 2017). Thus, the development of a hamburger of bean tempeh can be a good market opportunity.

Manufacturing process suffers from contamination by bacteria, fungi and yeasts during fermentation. The raw material itself contains a bacterial burden, including Lactobacillus casei, Enterococci, Staphylococci, Streptococci, Bacilli, Enterobacter, Klebsiella, aside from other coliforms. A total of 16 million cases of inflammatory fever includes salmonellose, 1.3 billion cases of gastroenteritis and 3 million deaths from Salmonella sp. worldwide each year (Wibisono et al., 2020). Therefore, hygienicsanitary precautions during food processing are one of the main preventive measures to prevent microbiological contamination. In 2012, 89 cases of gastroenteritis caused by Salmonella in North Carolina were associated with the consumption of unpasteurized tempeh (Griese et al., 2013). All food needs to be safe and, in this sense, the bean tempeh, as an innovative food of economic importance and scientific contribution, requires a production method that assures its microbiological quality.

Aged bean grains represent an economic problem, as they are rejected by consumers. Therefore, the use of these in the development of new products is an alternative to reuse these, in addition to providing foods with high nutritional value. In this contest, this work proposes a method for producing bean tempeh, and subsequent hamburger production from bean tempeh. So, this work aims to grow Rhizopus inoculum for tempeh production from aged common bean under Brazilian food technical 
regulations (BRASIL, 2001), to apply it as an ingredient of sensory accepted vegan hamburger and defining the procedure for tempeh preparing in compliance with regulation on standards for acceptable microbiological contamination. Moreover, verify the sensorial acceptance of a hamburger produced with the best tempeh developed.

\section{Methodology}

\subsection{Material}

The carioca commercial type of common bean cv. Pérola and the conventional soybean cv. BRS284 were harvested at Embrapa Arroz e Feijão (2015), processed (natural drying and cleaning) and homogenized before storage at room temperature for 18 months. Healthy aged grains were kept in a cold room $\left(5^{\circ} \mathrm{C}\right)$ until use. The Rhizopus oligosporus strain was acquired from Tropical Cultures Collection of André Tosello Research and Technology Foundation, in Campinas (SP, Brazil). Commercial (frozen) soybean tempeh was purchased from manufacturer in Resende (RJ, Brazil) as reference sample.

\subsection{Water absorption rate}

After washing the grains under running water, $200 \mathrm{~g}$ of each cultivar were soaked in $500 \mathrm{~mL}$ of distilled water at room temperature $\left(25^{\circ} \mathrm{C}\right)$. In order to build a reasonable water absorption curve, beans were taken from container by using a sieve at 30 minutes intervals $(0,30,60,90,120,150,180,210$ and $240 \mathrm{~min}$.). After this, the samples were taken at 4-hour intervals (4, 8 and 16 hours) adapted from Berrios, Swanson, and Cheong (1999), and finally dried in paper towel and weighed in analytical balance. Water absorption rate was calculated in \% considering the grain weight gain after hydration.

\subsection{Multiplication of Rhizopus oligosporus and spore count}

Rhizopus sp. strain was transferred to Petri dishes with PDA (Potato Dextrose Agar) medium to increase spore production. After mycelial growth and spore formation, the surface of each plate was scraped with a platinum loop and the mycelia were transferred to a conical flask containing $100 \mathrm{~mL}$ of sterile distilled water. From this suspension, counts were performed in Neubauer's chamber. In order to determine the optimal culture medium for inoculum production, Rhizopus strain was seeded in Petri dishes containing the following media: PDA, PDA + rice flour (RF), PDA + bean flour (BF), PDA + 50\% $\mathrm{RF}+50 \% \mathrm{BF}$. Autoclaved culture media were inoculated in a laminar flow chamber and incubated in an oven at $30^{\circ} \mathrm{C}$ for $48 \mathrm{~h}$. The medium that presented the best fungal development was selected for inoculum preparation. Spore count was performed using Neubauer chamber (Global Trade, improved double chamber - BSN 020).

\subsection{Inoculum preparation}

According to Cruz (2014), 100g of polished rice grains were ground, sieved on an electromagnetic vibrating screen BERTEL ${ }^{\circledR}$ using 200 mesh sieves. Flour was placed in glass containers with metal lid, which were sterilized and let to cool. In each container, $20 \mathrm{~mL}$ of suspension was inoculated and incubated at $30^{\circ} \mathrm{C}$ for 5 days. After this time, containers were refrigerated and used for up to 30 days.

\subsection{Production of tempeh}

After completion of all the previous steps, the raw material was inoculated, and fermentation process started. During this step, the development of Rhizopus oligosporus mycelia was monitored visually until the entire extent of raw material was occupied by the fungus. This moment was defined when the fermentation step was complete. Three replicates of tempeh samples of dehulled beans were produced in different proportions: 50\% bean / 50\% soybean (SBT) and 100\% bean (BT) and compared with the control, 100\% soybean (ST) tempeh. For both cultivars, tempeh was made according to Indonesian traditional method, 
following the steps described by Kuswanto (2004) (Figure 1) and by a modified method proposed by Starzyńska-Janiszewska, Stodolak, and Mickowska (2014) (Figure 2).

Figure 1. Flowchart: tempeh traditional production steps.

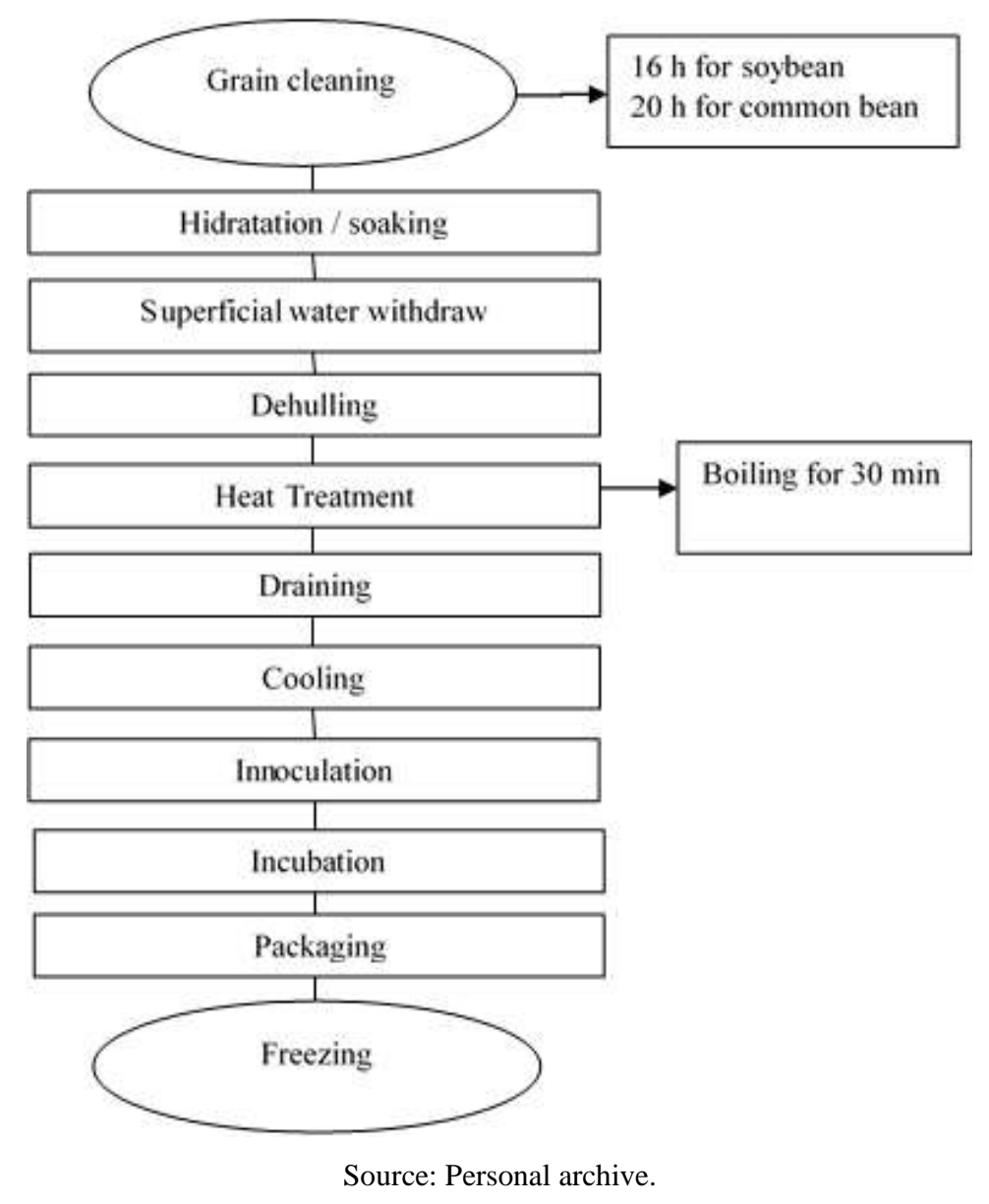

\subsection{Microbiological Analyses}

Tempehs microbiological quality was evaluated based on the acceptable limits of total coliform count at $45^{\circ} \mathrm{C}$, fecal coliforms at $45^{\circ} \mathrm{C}$, coagulase-positive Staphylococci and Salmonella sp., described by the Technical Regulation on Microbiological Standards for Food, RDC No. 12 of January 2nd, 2001 - ANVISA (Brasil, 2001), using a similar fermented soybean paste (miso) as reference. Microbiological analysis was performed in triplicate following the Compedium of Methods for the Microbiological Examination of Foods (Salfinger \& Tortorello, 2015).

\subsection{Hamburger production}

The hamburgers were made from ST and BT with equal ingredients proportions (100 g ST or BT, $2 \mathrm{~g}(2 \%)$ salt, $2 \mathrm{~g}$ (3\%) pepper, $3 \mathrm{~g}(3 \%)$ dehydrated onion, $3 \mathrm{~g}(3 \%)$ dehydrated garlic, $4 \mathrm{~g} \mathrm{(4 \% )}$ dehydrated parsley, $4 \mathrm{~g} \mathrm{(4 \% )}$ dehydrated chives and $50 \mathrm{ml}$ olive oil). The burgers were grilled in non-stick frying pan, greased with olive oil until golden brown on both sides. Each $100 \mathrm{~g}$ of tempeh yielded an average of 11 small burgers (of around $15 \mathrm{~g}$ each). 
Figure 2. Flowchart: production steps of common bean and soybean modified tempeh.

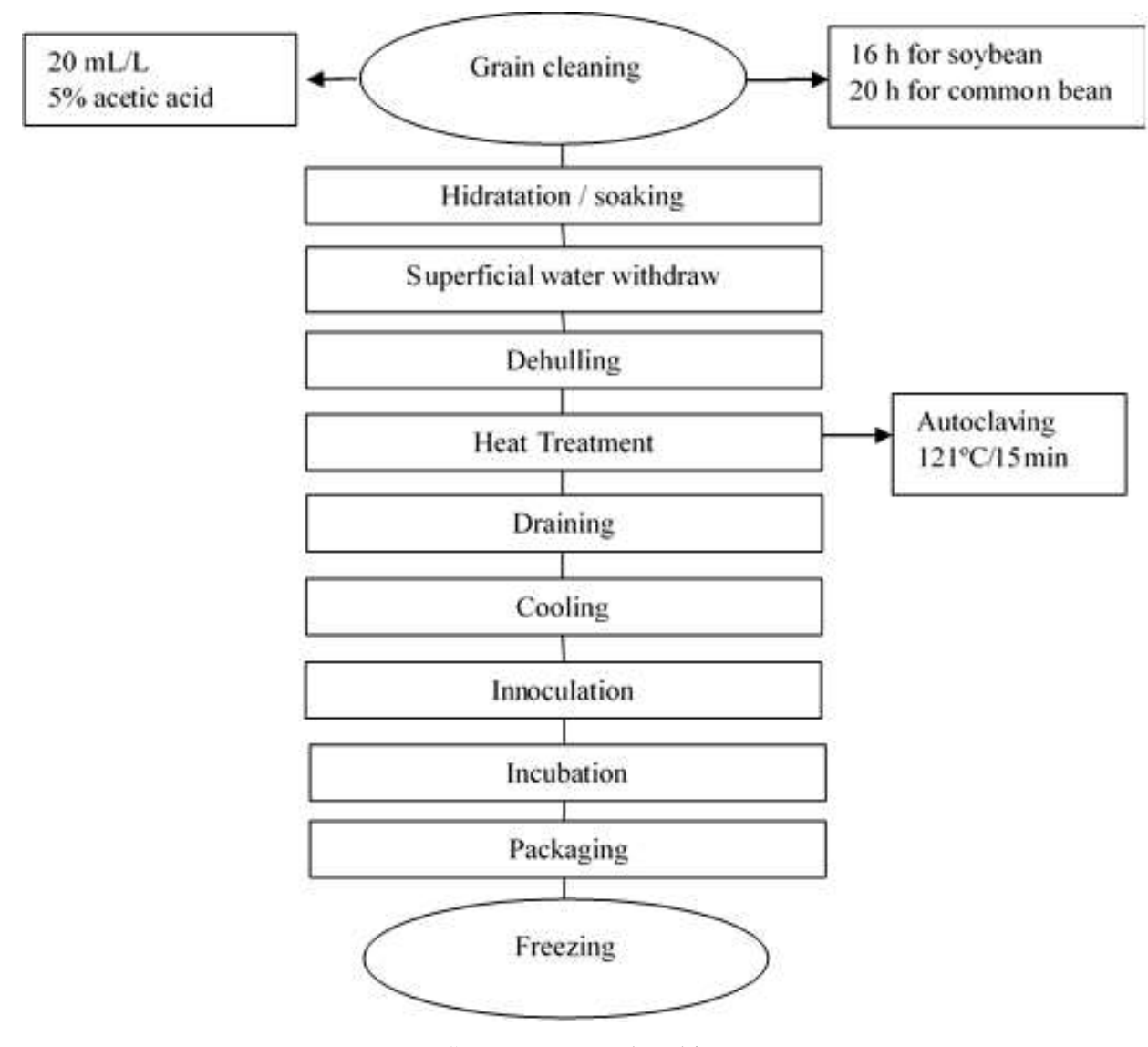

Source: Personal archive.

\subsection{Sensorial evaluation and purchase intention of hamburger}

The bean tempeh (BTH) and soybean tempeh (STH) hamburgers were evaluated by 82 untrained tasters (39\% men from 19-55 yrs. old and $60.98 \%$ women from 19-52 yrs. old) regarding the acceptance of appearance, aroma, flavor and overall impression, using a nine-point hedonic scale (9- I liked it very much and 1-I greatly disliked it). The testers were also asked about the intention to buy the product, using a 5-point scale (5 would certainly buy this product and 1-certainly would not buy this product). (Project approved by the Ethic committee: protocol $\mathrm{n}^{\circ}$. 60631116.6.0000.5083; certificate approval code 1.978.775).

\section{Results and Discussion}

\subsection{Inoculum development and fermentation}

Soybean grains absorb water faster than beans (Figure 3). Between 8 and 20 hours of imbibition, soybean kept constant weight, unlike the beans that continued to absorb water up to 20 hours. This phenomenon can be explained due to the bean hull: thicker, less malleable and more adherent to cotyledon than soybean (Cavariani, Toledo, Rodella, França Neto, \& Nakagawa, 2009; Olivo, de Tunes, Olivo, Bertan, \& Peske, 2011). During soaking, water diffuses into bean grain, promoting the increase of volume. Water absorption by grains during soaking increases along with the increasing on temperature and time (Resende $\&$ Correa, 2007).

Hydration is understood as a physical process related to tegument permeability and the properties of grain's constituent colloids. Water absorption rate depends on chemical composition, permeability of integument and the presence of water in liquid or gaseous forms in the medium where process is occurring (Nicolin, Jorge, \& Jorge, 2017). Cavariani et al. (2009) affirm that 
tegument permeability affects the soybean hydration rate due to variations in thickness, composition, cultivar, and place of production. In this sense, gelatinization of starch is considered one of the main reasons for hydration.

Figure 3. Water absorption curve of common bean grain and soybean at room temperature.

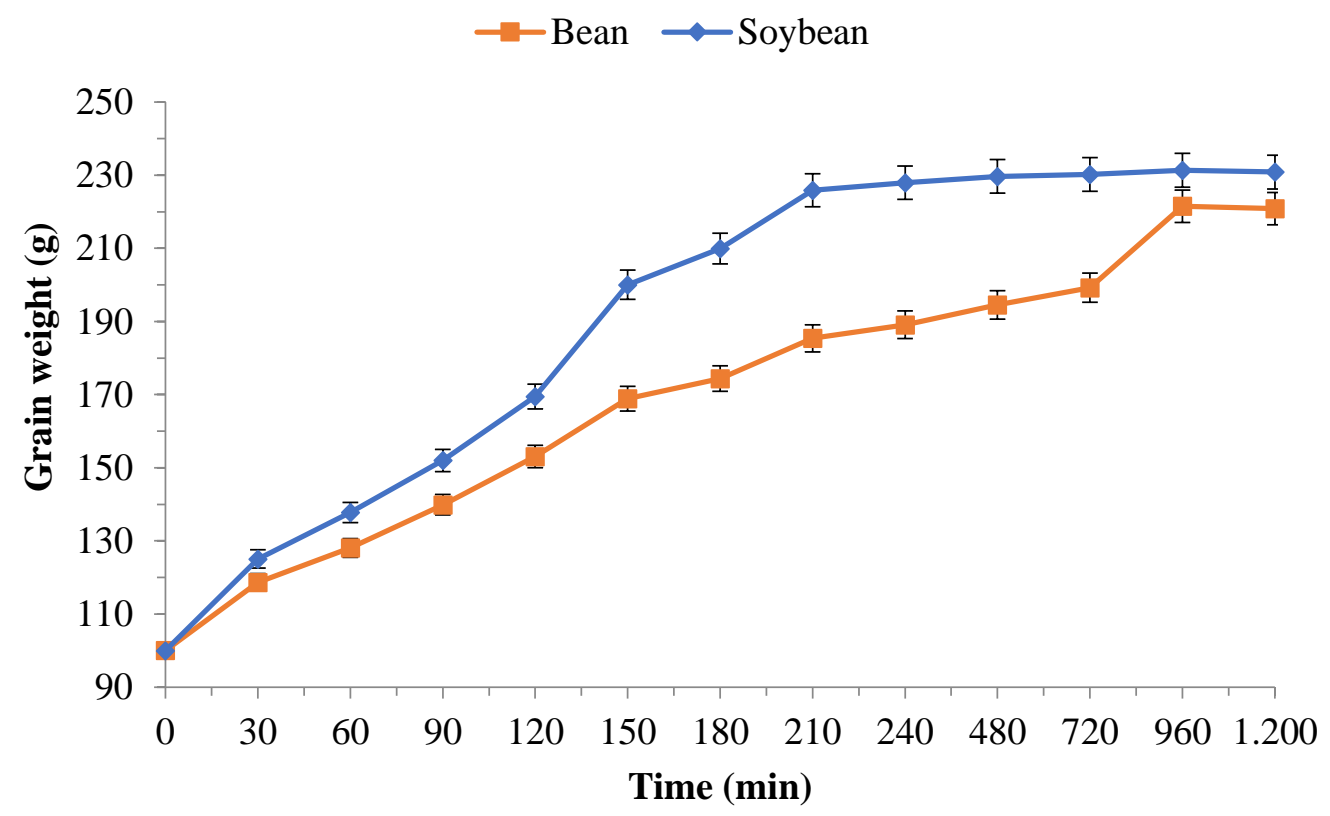

Source: Personal archive.

After 48 hours of fermentation, it was observed by visual evaluation that all culture media in Petri dishes provided condition for fungus development. However, culture medium containing white rice flour (Figure 4A) and the one containing only PDA (Figure 4B), provided a better mycelia development. These data are in accordance with Cruz (2014); Nout and Kiers (2005); Ruiz-Terán and David Owens (1996) who concluded that PDA medium provides abundant growth of mycelium, since it is a richer medium. Thus, the medium containing only PDA was selected for the present work.

Figure 4. Development of Rhizopus oligosporus in PDA medium with Rice (A) and in PDA medium only (B).

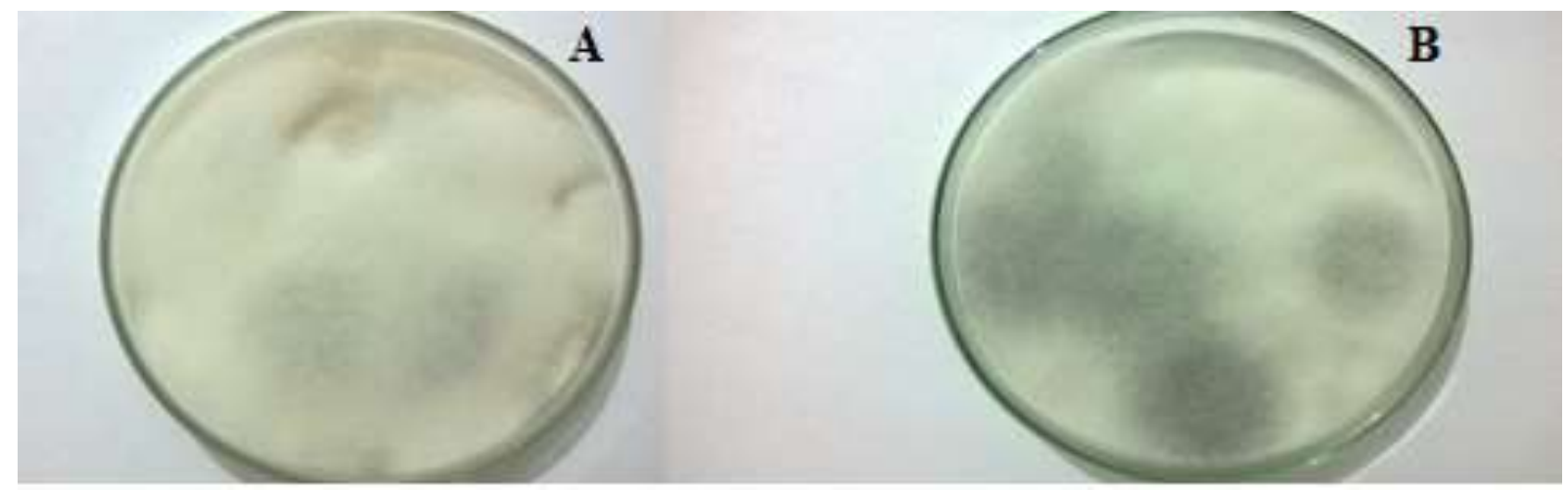

Source: Personal archive.

Inoculum cells counting was based on the suspension volume in Neubauer's chamber of $0.1 \mathrm{~mm}^{3}$, resulting in a spore counting of $10^{6}$ cells $/ \mathrm{mL}$. Thus, $20 \mathrm{~mL}$ of spore suspension were inoculated in $100 \mathrm{~g}$ of milled and sterilized white rice flour. It was observed that grain fermentation of tempehs occurred gradually. For both tempehs no development was observed in the first 
8 hours, however, BT presented mycelial formation from 12 hours on, and SBT from 16 hours on. Tempehs were considered ready, with complete fermentation, when all grains were involved with mycelium, in 24 hours for BT and in 30 hours for SBT. According to Sanjukta and Rai (2016), soybean fermentation in tempeh manufacturing requires approximately 20 hours to be completed, which may vary according to the concentration of inoculum. Inoculum with low concentration of viable cells increases fermentation time, allowing contamination by other microorganisms; on the other hand, high concentration of spores in inoculum negatively affects the formation of compounds that constitute tempeh flavor due to rapid fermentation.

It was noted that soybean ferments easier than beans; soybean carbohydrates (stachyose, raffinose and sucrose) are not the only sources of carbon consumed by Rhizopus oligosporus. Shiga, Cordenunsi, and Lajolo (2009) showed that scanning electron microscopy indicated that enzymes are secreted by fungus to facilitate chemical degradation of substrate compounds. Microbial growth may be followed by consumption of simple sugars such as glucose, fructose, maltose and xylose. Part of bean carbohydrates are in form of starch and fiber, where 17-23\% are basically composed of pectin, cellulose and hemicellulose. Rhizopus oligosporus has high proteolytic activity, important for its growth on protein substrates, but low activity of amylase and pectinase enzymes (Starzyńska-Janiszewska et al., 2014; Vong, Hua, \& Liu, 2018).

Traditional tempeh (ST), made with soybean, presents a firm format, soft consistency and it is surrounded by white mycelia. BT sample presented the closest appearance to the traditional product due to the mycelial uniformity and fermentation time. SBT fermentation was considered unsatisfactory, as it did not present good consistency (absence of cake consistency) and mycelial uniformity (fungus covering all grains). Formation of black dots were noted, indicating fermentation time was exceeded, and even so, the formation of characteristic white mycelium was not present. Different tempeh raw materials provide different fermentation times, as bean polysaccharides have a higher molecular weight than soybean and, when mixed, are possibly more difficult to be hydrolyzed by $R$. oligosporus enzymes. Considering all these factors, SBT samples were discarded from some further analyzes.

\subsection{Traditional method versus modified method}

Tempeh obtained by different methods (traditional and modified) was tested for microbiological contamination (Table 1). Use of traditional method did not prevent bacterial development, which was above the limits allowed by regulation (Brasil, 2001). Results were uncountable until the dilution $10^{-4}$ for all tempehs, despite the good practices adopted. There was no growth in control plate.

This result was expected since traditional method has some steps that allow microorganism development, since barriers that eliminate or prevent proliferation are not present. The quality of tempeh can be affected due to contamination with bacteria, fungi and yeasts developed during fermentation process. Therefore, a high level of sanitary practices during production is necessary, additionally to properly refrigerating or freezing product once fermentation is complete (Efriwati, Suwanto, Rahayu, $\&$ Nuraida, 2013). Moreover, the $\mathrm{pH}$ increase during fungal fermentation emphasizes the importance of acidification during soaking step, as this process is responsible for inactivation of potential pathogens that may be present in the raw material. The addition of acetic acid in modified method is a good manufacturing alternative, since most bacteria develop at pH close to neutral. 
Table 1. Results of microbiological analyses of tempeh produced by traditional and modified methods.

\begin{tabular}{lllll}
\hline \multirow{2}{*}{ Evaluations } & \multicolumn{2}{l}{ Traditional method } & \multicolumn{2}{l}{ Modified method } \\
\cline { 2 - 5 } & $\mathrm{BT}$ & $\mathrm{ST}$ & $\mathrm{BT}$ & $\mathrm{ST}$ \\
\hline Total Coliforms & $\geq 10^{4} \mathrm{UFC} / \mathrm{g}$ & $\geq 10^{4} \mathrm{UFC} / \mathrm{g}$ & $\geq 10^{4} \mathrm{UFC} / \mathrm{g}$ & $\leq 10 \mathrm{UFC}$ \\
Fecal Coliforms & $\geq 10^{4} \mathrm{UFC} / \mathrm{g}$ & $\geq 10^{4} \mathrm{UFC} / \mathrm{g}$ & $\geq 10^{4} \mathrm{UFC} / \mathrm{g}$ & $\leq 10 \mathrm{UFC}$ \\
Positive coagulase Staphilococci & $\geq 10^{4} \mathrm{UFC} / \mathrm{g}$ & $\geq 10^{4} \mathrm{UFC} / \mathrm{g}$ & $\geq 10^{4} \mathrm{UFC} / \mathrm{g}$ & $\leq 10 \mathrm{UFC}$ \\
Salmonella sp. & Absence in $25 \mathrm{~g}$ & Absence in $25 \mathrm{~g}$ & Absence in $25 \mathrm{~g}$ & Absence in $25 \mathrm{~g}$ \\
\hline
\end{tabular}

BT: common bean tempeh; ST: soybean tempeh. Source: Authors.

In modified method, where acidification and autoclaving steps were included, there was no development of bacterial typical colonies (Table 1), while the present fungi showed characteristics remarkably similar to those of Rhizopus oligosporus. As affirmed by Starzyńska-Janiszewska et al. (2014), autoclaving and keeping the good practices during tempeh production process are effective to control pathogens. Previously, a good fermentation and sanitary safety for soybean tempeh production was also achieved when applying autoclaving $\left(121^{\circ} \mathrm{C} / 10\right.$ minutes $)$ in lactic acid medium to obtain sterile and acidified cotyledons (Ruiz-Terán \& David Owens, 1996).

\subsection{Acceptance of hamburgers of common bean and soybean tempeh}

The appearance of the hamburgers was the attribute best rated for both products (BTH and STH). For the other items evaluated, the STH presented the highest scores, being considered sensorial accepted once it presented an acceptance index greater than 70\% (Bastos, Paulo, \& Chiaradia, 2014; Dutcosky, 2019) (Table 2).

Table 2. Mean scores for sensory attributes and acceptance index (AI) of tempeh hamburgers.

\begin{tabular}{lcccc}
\hline & \multicolumn{2}{c}{ BTH } & \multicolumn{2}{c}{ STH } \\
\cline { 2 - 5 } & mean & ${ }^{1} \mathrm{AI}(\%)$ & mean & ${ }^{1} \mathrm{AI}(\%)$ \\
\hline Appearance & $6.82 \pm 0.76$ & 75.74 & $6.93 \pm 0.54$ & 77.10 \\
Flavor & $5.84 \pm 0.47$ & 64.90 & $6.54 \pm 0.49$ & 72.76 \\
Taste & $4.50 \pm 0.51$ & 50.00 & $6.35 \pm 0.46$ & 70.59 \\
Overall impression & $5.28 \pm 0.37$ & 58.70 & $6.40 \pm 0.44$ & 71.14
\end{tabular}

Mean followed by standard deviation; BTH: bean tempeh hamburgers; STH: soybean tempeh hamburgers. ${ }^{1}$ Sensory acceptance index $(\%)$ (AI $(\%)=\mathrm{A} \times 100 / \mathrm{B}$, where: $\mathrm{A}=$ average grade obtained for the product; $\mathrm{B}=$ maximum grade given to the product). Source: Bastos et al. (2014).

The low notes for the taste and flavor attributes of BTH might be due to a mixture of perceived olfactory, gustatory, and tactile sensations which are different from those associated to a sensory memory of the traditional meat hamburger taste. The bean flavor is more intense and evident than that of the soybean, and its application as a main ingredient of hamburger is a very new idea, disfavoring somehow the evaluation of the product. In addition, in the comments left by the tasters, the perception of a residual bitter taste in BTH and STH samples was evidenced. One hypothesis to improve the acceptance of tempeh hamburgers is to adjust some manufacturing steps, like cooking grains for a longer time.

For the tempeh to be considered with good acceptance, the average note must be of value greater than 5 . Notes below 5 were considered unsatisfactory to consider the tempeh accepted in the judgment of the tasters, being disapproved. Therefore, the low notes obtained by the bean tempeh hamburger characterize it as a non-sensorial accepted product. Therefore, the improvement of the tempeh production technique and new ingredients for the hamburgers are important steps to obtain greater 
acceptability of this new product. The BT is an innovative product that may contributes to the use of depreciated beans, as well as an alternative for the consumption of healthy foods. The promotion of new bean products promotes the spread of tempeh and awakens the consumer's curiosity to try non-conventional products.

Regarding the purchase intention, the soy tempeh hamburger received a higher score, which is consistent with the previous results ( $40.24 \%$ of the tasters would buy the STH and $30.48 \%$ would buy BTH). The low intention to buy is because consumers associate the hamburger with the characteristics of succulence, frying odor, meat flavor and darker color. When faced with the samples, the expectation that is created for the consumption of this food is broken by the difference of the traditional hamburgers (of meat) and the one of tempeh. However, the hamburger may be one of the possibilities of tempeh application, and can be indicated as a product for vegans, vegetarians, or even the public looking for a product with high protein content of vegetable origin. Thus, the products developed showed high nutritional value and great market potential. In addition, they are vegan and gluten-free products, which serve a portion of consumers who have dietary restrictions or who seek a healthy and modern diet.

\section{Conclusion}

The production of tempeh using dehulled carioca bean is feasible when using $10^{6}$ spores of Rhizopus sp. per $\mathrm{mL}$ during inoculation and incubation at $30^{\circ} \mathrm{C}$ for 24 hours. The modified method: autoclaving at $121^{\circ} \mathrm{C}$ for 15 minutes and acidification with 5\% acetic acid in soaking step, were efficient to provide a safer food. Tempeh may be an interesting option for the use of commercially low-value grains and for adding value to common beans. The hamburger made with soybean presented the highest sensorial scores, being considered sensorial accepted. On the other hand, the low notes obtained by the bean tempeh hamburger characterize it as a non-sensorial accepted product. So, the hamburger made with bean tempeh needs to be improved further. Moreover, the common bean tempeh is an innovative product that may contribute to the use of depreciated grains, as well as an alternative for the consumption of healthy foods like vegan hamburgers.

\section{Acknowledgments}

To the Coordination for Improvement of Graduated Personnel [Capes], by financial support, Brazilian Agricultural Research Company [Embrapa Arroz e Feijão] and Metropolitan Faculty of Anápolis for technical support.

\section{References}

Bascunan, K. A., Vespa, M. C., \& Araya, M. (2017). Celiac disease: understanding the gluten-free diet. Eur J Nutr, 56(2), 449-459. 10.1007/s00394-016-12385

Bassinello, P. Z., Bento, J. A. C., Gomes, L. d. O. F., Caliari, M., \& Oomah, B. D. (2020). Nutritional value of gluten-free rice and bean based cake mix. Ciência Rural, 50. https://doi.org/10.1590/0103-8478cr20190653

Bastos, G. A., Paulo, E. M., \& Chiaradia, A. C. N. (2014). Acceptability of potentially probiotic cereal bars. Brazilian Journal of Food Technology, $17(2), 113$.

Bento, J. A. C., Bassinello, P. Z., Colombo, A. O., Vital, R. J., \& Carvalho, R. N. (2020). Nutritional and Bioactive Components of Carioca Common Bean (Phaseolus vulgaris L.) Tempeh and Yellow Soybean (Glycine max L.) Tempeh. Current Nutrition \& Food Science, 16, 1-8. http://dx.doi.org/10.2174/1573401316666200121111854

Bento, J. A. C., Lanna, A. C., Bassinello, P. Z., Oomah, B. D., Pimenta, M. E. B., Carvalho, R. N., \& Moreira, A. S. (2020). Aging indicators for stored carioca beans. Food research international, 134(109249), 1-11. https://doi.org/10.1016/j.foodres.2020.109249

Berrios, J., Swanson, B. G., \& Cheong, W. A. (1999). Physico-chemical characterization of stored black beans (Phaseolus vulgaris L.). Food research international, 32(10), 669-676. 10.1016/s0963-9969(99)00144-1

Brasil. (2001). Resolução RDC 12 de 2 de janeiro de 2001. In A. N. d. V. Sanitária (Ed.), Regulamento Tecnico Sobre Padrões Microbiologicos Para Alimentos. Brasília, DF: Diário oficial da união.

Cavariani, C., Toledo, M. Z., Rodella, R. A., França Neto, J. d. B., \& Nakagawa, J. (2009). Velocidade de hidratação em função de características do tegumento de sementes de soja de diferentes cultivares e localidades. Revista Brasileira de Sementes, 31, 30-39. http://dx.doi.org/10.1590/S0101-31222009000100004 
Cruz, I. L. (2014). Desenvolvimento de um inóculo seguro, eficiente e padronizado para a produção de tempeh em pequena escala a partir de diferentes leguminosas. (Master ), University of Lisbon, Lisbon, Portugal. Retrieved from http://hdl.handle.net/10400.5/6799

de Farias, H. F. L., Devilla, I. A., Silva, A. P., Bento, J. A. C., \& Bassinello, P. Z. (2020). Modeling the color and hardness of beans according to storage conditions. Research, Society and Development, 9(7), e725974414. http://dx.doi.org/10.33448/rsd-v9i7.4414

Dutcosky, S. (2019). Análise sensorial de alimentos (5 ed.). Curitiba: Champagnat.

Efriwati, Suwanto, A., Rahayu, G., \& Nuraida, L. (2013). Population Dynamics of Yeasts and Lactic Acid Bacteria (LAB) During Tempeh Production. HAYATI Journal of Biosciences, 20(2), 57-64. https://doi.org/10.4308/hjb.20.2.57

Griese, S. E., Fleischauer, A. T., MacFarquhar, J. K., Moore, Z., Harrelson, C., Valiani, A., \& Davies, M. (2013). Gastroenteritis outbreak associated with unpasteurized tempeh, North Carolina, USA. Emerging infectious diseases, 19(9), 1514-1517. 10.3201/eid1909.130334

Krisnawati, A., \& Adie, M. M. (2015). Selection of Soybean Genotypes by Seed Size and its Prospects for Industrial Raw Material in Indonesia. Procedia Food Science, 3, 355-363. https://doi.org/10.1016/j.profoo.2015.01.039

Kuswanto, K. R. (2004). Industrialization of tempeh fermentation. In K. Steinkraus (Ed.), Industrialization of indigenous fermented foods, revised and expanded (pp. 587-630). New York: CRC Press.

Nakajima, N., Nozaki, N., Ishihara, K., Ishikawa, A., \& Tsuji, H. (2005). Analysis of isoflavone content in tempeh, a fermented soybean, and preparation of a new isoflavone-enriched tempeh. J Biosci Bioeng, 100(6), 685-687. 10.1263/jbb.100.685

Nicolin, D. J., Jorge, R. M. M., \& Jorge, L. M. M. (2017). Effects of variable diffusivity on soybean hydration modelling as a Stefan problem. The Canadian Journal of Chemical Engineering, 95(5), 1004-1013. 10.1002/cjce.22732

Nout, M. J. R., \& Kiers, J. L. (2005). Tempe fermentation, innovation and functionality: update into the third millenium. Journal of Applied Microbiology, 98(4), 789-805. 10.1111/j.1365-2672.2004.02471.x

Olivo, F., de Tunes, L. M., Olivo, M., Bertan, I., \& Peske, S. T. (2011). Espessura do tegumento e qualidade física e fisiológica de sementes de feijão. Revista Verde de Agroecologia e Desenvolvimento Sustentável, 6(1), 22.

Resende, O., \& Correa, P. (2007). Modelagem matemática do processo de hidratação de sementes de feijão. Acta Scientiarum-agronomy, 29(3), 373-378. 10.4025/actasciagron.v29i3.387

Ruiz-Terán, F., \& David Owens, J. (1996). Chemical and Enzymic Changes During the Fermentation of Bacteria-Free Soya Bean Tempe. Journal of the Science of Food and Agriculture, 71(4), 523-530. 10.1002/(sici)1097-0010(199608)71:4<523::Aid-jsfa613>3.0.Co;2-r

Salfinger, Y., \& Tortorello, M. L. (2015). Compendium of methods for the microbiological examination offoods (Y. Salfinger \& M. L. Tortorello Eds. (5a ed.). Washington, DC: Amer Public Health Assn.

Sanjukta, S., \& Rai, A. (2016). Production of bioactive peptides during soybean fermentation and their potential health benefits. Trends in Food Science \& Technology, 50. 10.1016/j.tifs.2016.01.010

Shiga, T. M., Cordenunsi, B. R., \& Lajolo, F. M. (2009). Effect of cooking on non-starch polysaccharides of hard-to-cook beans. Carbohydrate Polymers, 76(1), 100-109. https://doi.org/10.1016/j.carbpol.2008.09.035

Starzyńska-Janiszewska, A., Stodolak, B., \& Mickowska, B. (2014). Effect of controlled lactic acid fermentation on selected bioactive and nutritional parameters of tempeh obtained from unhulled common bean (Phaseolus vulgaris) seeds. Journal of the Science of Food and Agriculture, 94(2), 359-366. 10.1002/jsfa.6385

Vong, W. C., Hua, X. Y., \& Liu, S.-Q. (2018). Solid-state fermentation with Rhizopus oligosporus and Yarrowia lipolytica improved nutritional and flavour properties of okara. LWT Food Science Tecnology, 90, 316-322. https://doi.org/10.1016/j.lwt.2017.12.050

Wibisono, F. M., Wibisono, F. J., Effendi, M. H., Plumeriastuti, H., Hidayatullah, A. R., Hartadi, E. B., \& Sofiana, E. D. (2020). A review of salmonellosis on poultry farms: public health importance. Systematic Reviews in Pharmacy, 11(9), 481-486.

Yannakoulia, M., Mamalaki, E., Anastasiou, C. A., Mourtzi, N., Lambrinoudaki, I., \& Scarmeas, N. (2018). Eating habits and behaviors of older people: Where are we now and where should we go? Maturitas, 114, 14-21. https://doi.org/10.1016/j.maturitas.2018.05.001 